\title{
Identification of a Selective Small-Molecule Ligand for HIV-1 Frameshift-Inducing Stem-Loop RNA from an 11,325 Member Resin Bound Dynamic Combinatorial Library
}

\author{
Brian R. McNaughton ${ }^{\dagger, \S}$, Peter C. Gareiss ${ }^{\zeta, \S}$, Benjamin L. Miller ${ }^{\ddagger}, \zeta, \S_{*}$ \\ Department of Biochemistry and Biophysics ${ }^{\zeta}$, Department of Chemistry ${ }^{\dagger}$, Department of Dermatology and the Center for Future \\ Health ${ }^{\S}$, University of Rochester, Rochester New York 14642
}

\section{Supplementary Data}

1. Preparation of solution phase and solid phase components

2. Dynamic light scattering data showing no degradation of

RNA over DCC experimental timeframe

3. RBDCC experimental procedure and results

4. Identification of selected building blocks by bead size and mass spectrometry data, and identification of highestaffinity ligands from a RBDCC sub-library

5. Preparation and spectral analysis of 1-1 and 1-3

6. Surface plasmon resonance (SPR) data and procedures S2-S4

7. Binding of Cy3-tagged RNA sequence I to resin-bound 1-1 in the presence of a large excess of tRNA

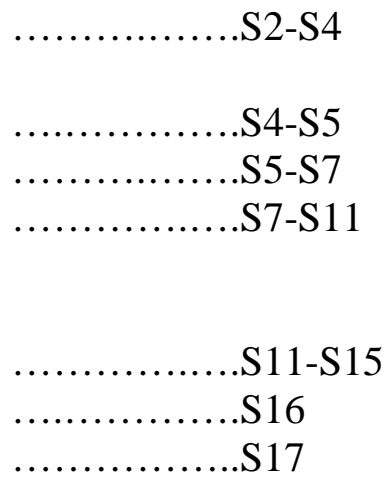

RNA and DNA was purchased from Integrated DNA Technologies ( $\geq 95 \%$ purity by HPLC)

Graphical analysis of SPR data was carried out using DeltaGraph (Rockware Inc.)

NMR spectral data were processed and analyzed using MestReC v. 4.4.1.0 (Mestrelab Research).

All vessels used in this research were sterilized before use.

Abbreviations:

DMF: dimethylformamide

THF: tetrahydrofuran

DCM: methylene chloride

MeOH: methanol

HATU: 2-(1H-7-Azabenzotriazol-1-yl)-

1,1,3,3-tetramethyl uronium hexafluorophosphate

DIPEA diisopropylethylamine
Trt: trityl

Anp: 3-amino-3-(2-nitrophenyl) propionic acid

TES triethylsilane

DMSO dimethylsulfoxide

TFA trifluoroacetic acid

SPR surface plasmon resonance 


\section{Preparation of solution phase components.}

\section{Synthesis of solution phase monomers:}

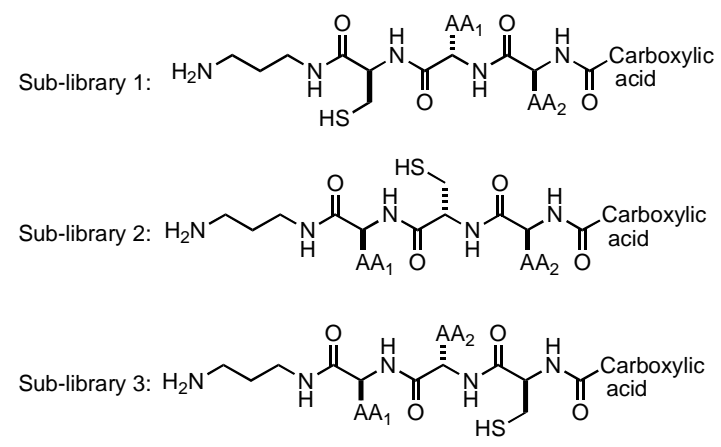

Synthesis of solution phase monomers was performed by standard split-pool synthesis employing FMOC chemistry. Three sub-libraries were independently prepared in which the position of the cysteine differs, so that cleavage of the resin results in a heterogeneous mixture containing an equal distribution of molecules having cysteine in position 1,2 , or 3 . Briefly, Wang resin (100-200 mesh size, $1 \mathrm{mmol} / \mathrm{g}$ loading) was activated through the addition of 1-1'carbonyl-di-imidizole (1620 mg, $5 \mathrm{mmol}, 10 \mathrm{eq})$ in $12 \mathrm{~mL}$ of DMF. This suspension was rotated on a LabQuake ${ }^{\mathrm{TM}}$ rotator for 12 hours. The vessel was then evacuated and washed three times with $15 \mathrm{~mL}$ DCM. Propane diamine $(421 \mu \mathrm{L}, 5 \mathrm{mmol}, 10 \mathrm{eq})$ was added in $12 \mathrm{ml}$ of DMF and rotated for an additional 12 hours. To this resin (sub-library 1) was added FMOC-Cys(Trt)-OH (879 mg, $1.5 \mathrm{mmol}, 3 \mathrm{eq}$ ), HBTU (570 mg, $1.5 \mathrm{mmol}, 3 \mathrm{eq}$ ), and DIPEA (424 $\mu \mathrm{L}, 2.5 \mathrm{mmol}, 5$ eq) in $10 \mathrm{ml} \mathrm{DMF}$, and rotated for 1 hour Following FMOC deprotection (20\% piperidine / DMF, 30 mins.) and washing as described previously, the resin was split into 5 vessels and amino acids 1-5 were coupled (in position $\mathrm{AA}_{1}$ ). Following FMOC deptotection the resin was pooled, split into five vessels, and amino acids 6-10 were coupled (in position $\mathrm{AA}_{2}$ ). Sublibraries 2 and 3 were prepared similarly, but varying the position of the cysteine residue. Following FMOC deprotection the resin was pooled, mixed, split into two vessels, and coupled to carboxylic acid 1 or 2.

Synthesis of each sublibrary was performed as described above. To couple amino acids 1-5 [1:(Fmoc-Lys(Boc)-OH (141 mg, 0.3 mmol, 3 eq), 2: (Fmoc-His(Trt)-OH (186 mg, 0.3 mmol, 3 eq), 3: (Fmoc-Ser(Trt)-OH (170 mg, 0.3 mmol, 3 eq), 4: (Fmoc-Phe-OH (116 mg, 0.3 mmol, 3 eq), 5: (Fmoc-Ala-OH•2 $\mathrm{H}_{2} \mathrm{O}$ (99 mg, $\left.\left.0.3 \mathrm{mmol}, 3 \mathrm{eq}\right)\right]$ were weighed out into 5 separate vials containing HBTU (114 mg, $0.3 \mathrm{mmol}, 3 \mathrm{eq}$ ), and DIPEA ( $85 \mu \mathrm{L}, 0.5 \mathrm{mmol}, 5 \mathrm{eq}$ ). $5 \mathrm{ml}$ of DMF was added to each vial, and the contents were added to separate vessels of washed resin and allowed to rotate for 30 minutes. To couple amino acids 6-10 [6:(Fmoc-Asn(Trt)-OH (178 mg, $0.3 \mathrm{mmol}, 3 \mathrm{eq})$, 7: (Fmoc-Val-OH (102 mg, $0.3 \mathrm{mmol}, 3 \mathrm{eq}), 8:$ (Fmoc-Pro-OH (101 mg, 0.3 mmol, 3 eq), 9: (Fmoc-Thr(Trt)-OH 175 mg, 0.3 mmol, 3 eq), 10: (Fmoc-Met-OH (99 $\mathrm{mg}, 0.3 \mathrm{mmol}, 3 \mathrm{eq})]$ were used and coupled as described above. After synthesis of the 3 amino acids was performed, each sub-library was split into two vessels. To couple carboxylic acids 1-2 [1:(3-carboxy-2-ethyl-3-quinolinium chloride $357 \mathrm{mg}, 2.25 \mathrm{mmole}, 3 \mathrm{eq}), 2$ :(piperizinoic acid $452 \mathrm{mg}, 2.25 \mathrm{mmole}, 3 \mathrm{eq})]$ were used and coupled as described above. The sublibraries were pooled and the resin was washed thoroughly. Lastly, products were cleaved, and Boc and Trt deprotected in $10 \mathrm{~mL}$ of a $1 \%$ TES / 50\% TFA solution in DCM for one hour. Compounds were 
purified by precipitation in chilled ether $\left(-20^{\circ} \mathrm{C}\right)$. Solids were concentrated by centrifugation (2500 rpm, $10 \mathrm{~min}$ ), the solution was removed, and fresh ether was added. The solution was mixed by vortex and solids were again concentrated by centrifugation. This series was repeated five times. After the last washing step the solids were dried by lyophilization, resulting in an off white powder.

\section{Preparation of solid phase components.}

Photolabile linker FMOC-Anp-OH was prepared using a published procedure. ${ }^{1}$

Three resins were used to encode the position of the cysteine residue.

Resin A: $140-170 \mu \mathrm{m}, 0.45 \mathrm{mmol} / \mathrm{g}, 0.86 \mathrm{nmol} / \mathrm{bead}$

Resin B: $200-250 \mu \mathrm{m}, 0.24 \mathrm{mmol} / \mathrm{g}, 1.50 \mathrm{nmol} / \mathrm{bead}$

Resin C: $280-320 \mu \mathrm{m}, 0.23 \mathrm{mmol} / \mathrm{g}, 3.50 \mathrm{nmol} / \mathrm{bead}$

All resin was made to be $0.86 \mathrm{nmol} / \mathrm{bead}$ by reacting with appropriate amounts of methoxyacetic acid in the presence of FMOC-Anp-OH.

$1 \mathrm{~g}$ of each resin type was placed in a separate reaction vessel and washed once with DCM.

To resin A was added FMOC-Anp-OH (583 mg, $1.35 \mathrm{mmol}, 3$ eq.), HBTU (513 mg, $1.35 \mathrm{mmol}$, 3 eq.), and DIPEA ( $391 \mu 1,2.25 \mathrm{mmol}, 5$ eq.) in $10 \mathrm{ml}$ of DMF. This solution was agitated for 4 hours on a LabQuake ${ }^{\mathrm{TM}}$ rotator.

To resin B was added FMOC-Anp-OH (332 mg, $0.77 \mathrm{mmol}, 1.71$ eq.), methoxyacetic acid (45 $\mu 1,0.58 \mathrm{mmol}, 1.29$ eq.) HBTU (513 mg, $1.35 \mathrm{mmol}, 3$ eq.), and DIPEA ( $391 \mu \mathrm{l}, 2.25 \mathrm{mmol}, 5$ eq.) in $10 \mathrm{ml}$ of DMF. This solution was agitated for 4 hours on a LabQuake ${ }^{\mathrm{TM}}$ rotator.

To resin $\mathrm{C}$ was added FMOC-Anp-OH (138 mg, $0.32 \mathrm{mmol}, 0.72 \mathrm{eq}$ ), methoxyacetic acid (79 $\mu \mathrm{l}, 1.03 \mathrm{mmol}, 2.28$ eq.) HBTU (513 mg, $1.35 \mathrm{mmol}, 3$ eq.), and DIPEA (391 $\mu \mathrm{l}, 2.25 \mathrm{mmol}, 5$ eq.) in $10 \mathrm{ml}$ of DMF. This solution was agitated for 4 hours on a LabQuake ${ }^{\mathrm{TM}}$ rotator.

Solid phase components were prepared using split-pool methodology analogous to the synthesis of solution phase components described above, with the exception of substituting FMOC-Cys$\mathrm{StBu}-\mathrm{OH}$ as the cysteine component. This was done to generate a disulfide protected cysteine on solid support to facilitate disulfide exchange between solid and solution phase components. Upon completion of solid phase building blocks, Trt and Boc protecting groups were removed by the addition of 1\% TES / 50\% TFA in DCM for 1 hour. Mass spectrometry data of the cleavage solution showed a single mass corresponding to trityl; therefore, it was concluded that no peptide product was cleaved from the resin.

1 Tan, D.S.; Foley, M.A.; Stockwell, B.R.; Shair, M.D.; Schreiber, S.L. Synthesis and Preliminary Evaluation of a Library of Polycyclic Small Molecules for Use in Chemical Genetic Assays. (Supplementary data), 1999, J. Am. Chem. Soc., 121, S12. 


\section{RNA does not significantly degrade over the course of the RBDCC experiment: Dynamic Light Scattering (DLS) data.}

DLS data was obtained on a DynaPro ${ }^{\mathrm{TM}}$ instrument. The RNA sequence was purchased as a lyophilized pellet, and diluted to a concentration of $500 \mu \mathrm{M}$ in phosphate buffer. ${ }^{2}$ A $100 \mu \mathrm{l}$ aliquot of the $500 \mu \mathrm{M}$ solution was placed in an eppeddorf tube. $15 \mu \mathrm{l}$ was removed by syringe, placed in a cuvette, and monitored immediately by DLS. The remaining solution was monitored by DLS after 72 hours, equivalent to the amount of time required for RBDCC experiments. DLS data was modeled as a sphere.

DLS data (1 hour):

DLS data showed a single species accounting for $98.1 \%$ of scatter, suggesting a monodisperse solution. This species showed a hydrodynamic radius $\left(\mathrm{R}_{\mathrm{H}}\right)$ of $1.82 \mathrm{~nm}(18.2 \AA)$ in size.

DLS data (72 hours):

DLS data showed a single species accounting for $95.1 \%$ of scatter, suggesting a monodisperse solution. This species showed a hydrodynamic radius $\left(\mathrm{R}_{\mathrm{H}}\right)$ of $1.79 \mathrm{~nm}(17.9 \AA)$ in size.

These data are in agreement with the NMR structure of this sequence (Figure S1), ${ }^{3}$ and suggest the RNA does not degrade over the course of the RBDCC experiments.

\footnotetext{
2 The phosphate buffer used in all DLS experiments was identical to that used in the RBDCC experiments. Stock solutions of (A) $0.2 \mathrm{M}$ monobasic sodium phosphate $(27.8 \mathrm{~g}$ in $1 \mathrm{~L}$ ), and (B) $0.2 \mathrm{M}$ dibasic sodium phosphate $\left(53.65 \mathrm{~g} \mathrm{Na}_{2} \mathrm{HPO}_{4} \bullet 7 \mathrm{H}_{2} \mathrm{O}\right.$ in $\left.1 \mathrm{~L}\right)$ were prepared. $19 \mathrm{ml}$ of $\mathrm{A}$ was mixed with $81 \mathrm{ml}$ of $\mathrm{B}$ and diluted to a final volume of $200 \mathrm{ml}$. To this solution was added $0.117 \mathrm{~g} \mathrm{NaCl}(10 \mathrm{mM})$. The $\mathrm{pH}$ of this buffer was found to be 7.45.

${ }^{3}$ Staple, D. W.; Butcher, S. E. J. Mol. Biol. 2005, 349, 1011-1023.
} 


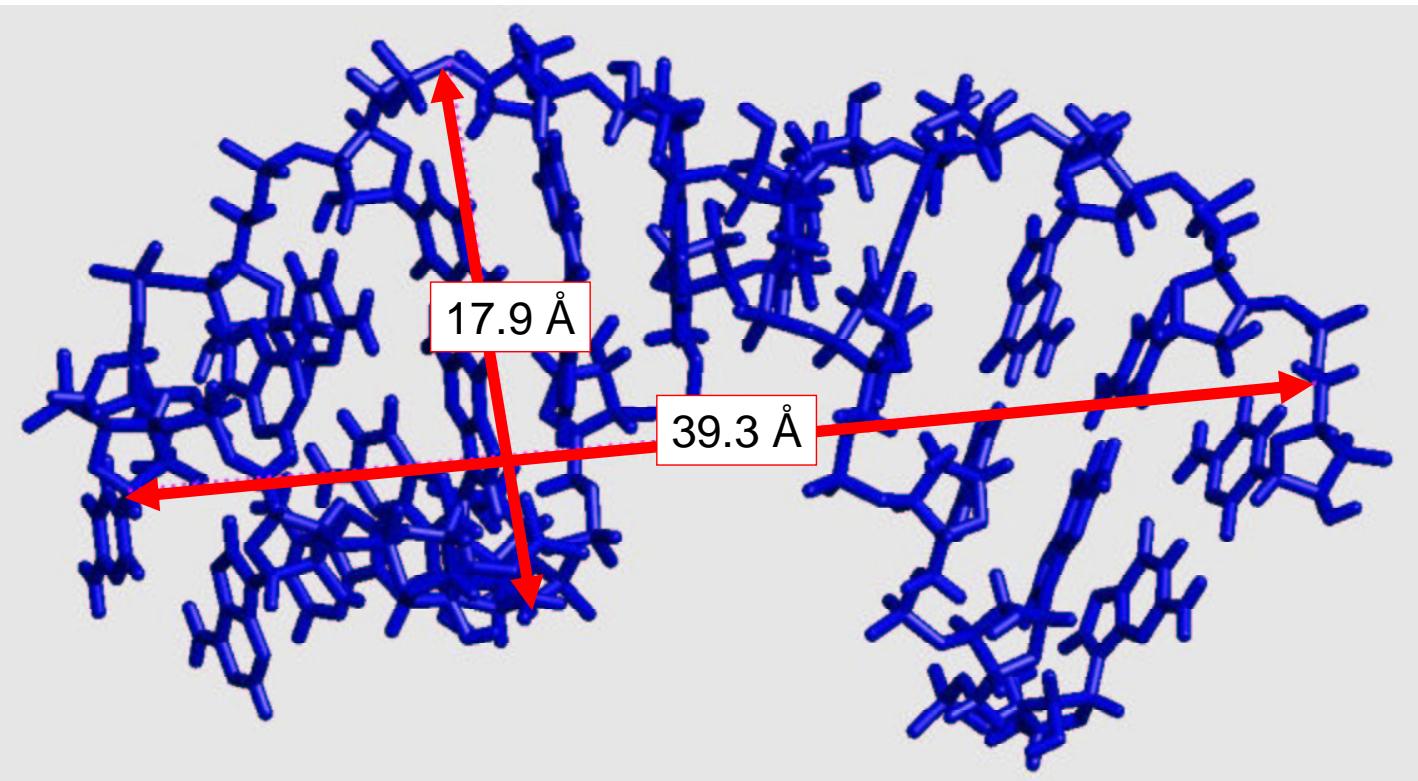

Figure S1. NMR structure of HIV-1 slippery sequence inducing stem-loop.

\section{RBDCC Experimental Procedure and Results.}

Figure S2. Resin Bound Dynamic Combinatorial Chemistry
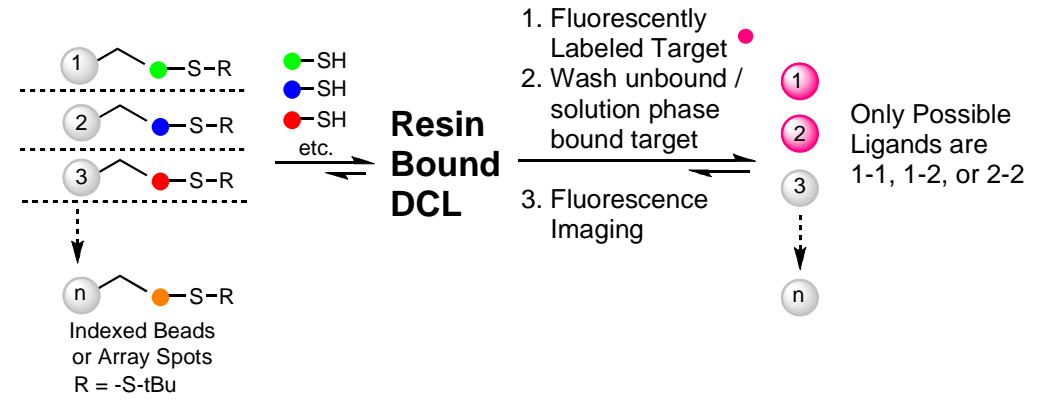

Next, RBDCC experiments were performed. First, as a control, 450 beads ( 150 of each size, 3 beads/compound, $387 \mathrm{nmol}$ total) were placed in a $1.5 \mathrm{ml}$ solid phase reaction vessel. To this was added a $1 \mathrm{ml}$ solution of $1 \mu \mathrm{M}$ RNA-Cy3 in phosphate buffer. This solution was agitated for 3 hours on a LabQuake ${ }^{\mathrm{TM}}$ rotator. After such time, the solution was drained by vacuum and washed three times with buffer $(1 \mathrm{ml}, 1 \mathrm{~min}$. each). After washing, the resin was suspended in $2 \mathrm{ml}$ buffer and placed in a Petri dish. Subsequent examination of the resin under a fluorescence microscope equipped with a $\mathrm{Cy} 3$ filter showed that no resin beads bearing single library building blocks bound the RNA with significant affinity under the conditions used. Next, RBDCC experiments were run in quadruplet. A heterogeneous mixture of solution phase building blocks ( $30 \mu \mathrm{M}$ based on average molecular weight) was equilibrated with solid phase building blocks (450 beads, 150 each size, $387 \mu \mathrm{M}$ total) and fluorescently labeled stem-loop RNA $(1 \mu \mathrm{M})$ in buffer (Figure S3). Solution phase components were prepared in a DMSO solution (0.1\% DMSO final concentration). Libraries were equilibrated in quadruplet for 72 
hours, a period of time shown by HPLC to be sufficient for equilibrium to be reached. After such time, the solution was removed from 1 of the 4 experiments, and the resin was washed with buffer, plated with $2 \mathrm{ml}$ buffer, and analyzed by fluorescence microscopy as described above. Using a washing scheme and exposure time identical to the control experiment described above resulted in a significant number of resin bearing similar fluorescence intensities. Ideally, only the highest affinity ligands are selected. Therefore, washing schemes as well as the exposure time on the microscope were adjusted while analyzing experiments 2 and 3 such that only a few resin beads were observed to exhibit fluorescence. In the fourth and final analysis, the strictest washing protocol was used (4 times, 90 seconds per wash), and an exposure time of $50 \mathrm{msec}$. was used.

Figure S3 Concentration of components used in RBDCC experiments.

\begin{tabular}{|c|c|c|c|c|c|}
\hline & $\begin{array}{l}\text { Solid-phase } \\
\text { component }\end{array}+$ & RNA + & $\begin{array}{c}\text { Solution-phase } \\
\text { component }\end{array}$ & $\stackrel{\text { RBDCL }}{\rightleftharpoons}$ & High-affinity ligands \\
\hline noles & $387 E^{-9}$ & $1.00 E^{-9}$ & $30 E^{-9}$ & & \\
\hline equiv. & 12.9 & $0.03 \mathrm{E}$ & 1.0 & & \\
\hline
\end{tabular}

Figure S4 Selection of high-affinity ligands from a mixture by fluorescence.

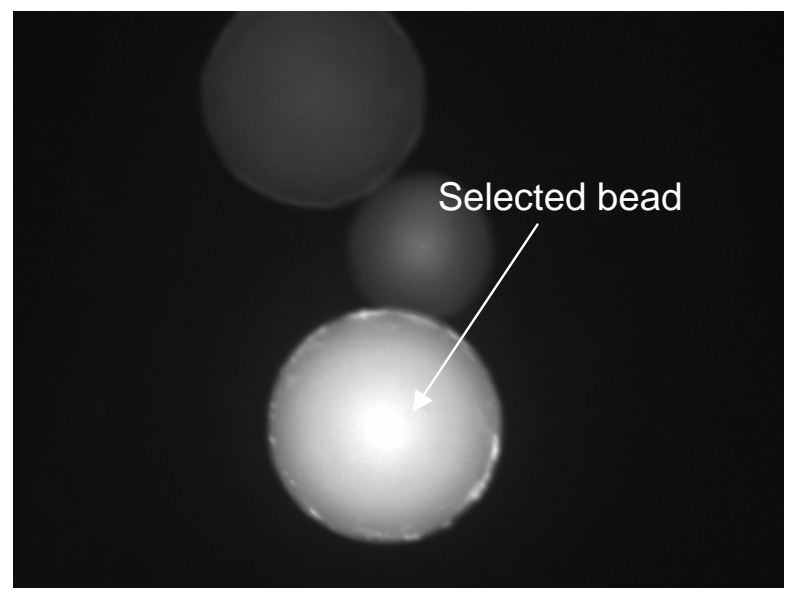

Under these conditions three beads were selected as exhibiting significant fluorescence (Figure S4). These beads were removed via syringe, and washed further to remove as much of the bound RNA as possible ( $5 \mathrm{x}$ DMF, $5 \mathrm{x}$ THF, $5 \mathrm{x}$ acetonitrile). Before cleavage, selected resin beads were measured to identify the position of the cysteine residue within the building block (Figure S5). Finally, the selected beads were cleaved by photolysis $(365 \mathrm{~nm})$ in eppendorf tubes containing $100 \mu \mathrm{L}$ acetonitrile:methanol (4:1) for 24 hours. The resulting solution was analyzed by mass spectrometry to identify unreacted thio-S-tBu monomers, which where the highest population species on the resin and therefore the most easily detected. ${ }^{4}$

\footnotetext{
${ }^{4}$ Mass spectrometry was performed at the University of Buffalo mass spectrometry facility. Data was obtained on a ThermoFinnigan MAT 95 XL spectrometer using electrospray ionization.
} 
Figure S5 Identification of cysteine position in structures on selected resin beads by size differentiation.

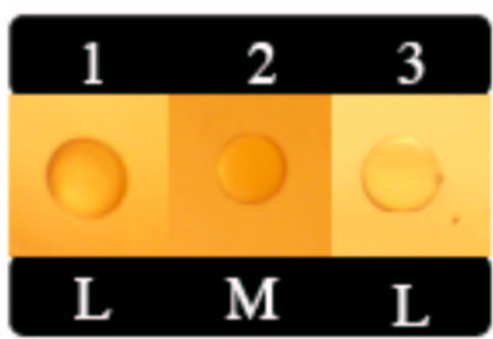

(Top: Bead number. Bottom: Bead size)

\section{Identification of high-affinity ligands by} bead size and mass spectrometry.

Masses of selected building blocks were then obtained (Figure S6). These masses correspond to building blocks 1, 2, and 3 (Figure S7).

Figure S6 Mass spectrometry data identifying building blocks which participate in the synthesis of high-affinity ligands.

(A) Cleavage of resin bearing photo-labile linker (Anp).

ROC-BRM-7-LCQ\#1-9 RT: 0.00-0.21 AV: 9 SB: 11 0.31-0.58 NL: 4.93E6

$\mathrm{T}:$ + c ESI Full ms [100.00-2000-00]

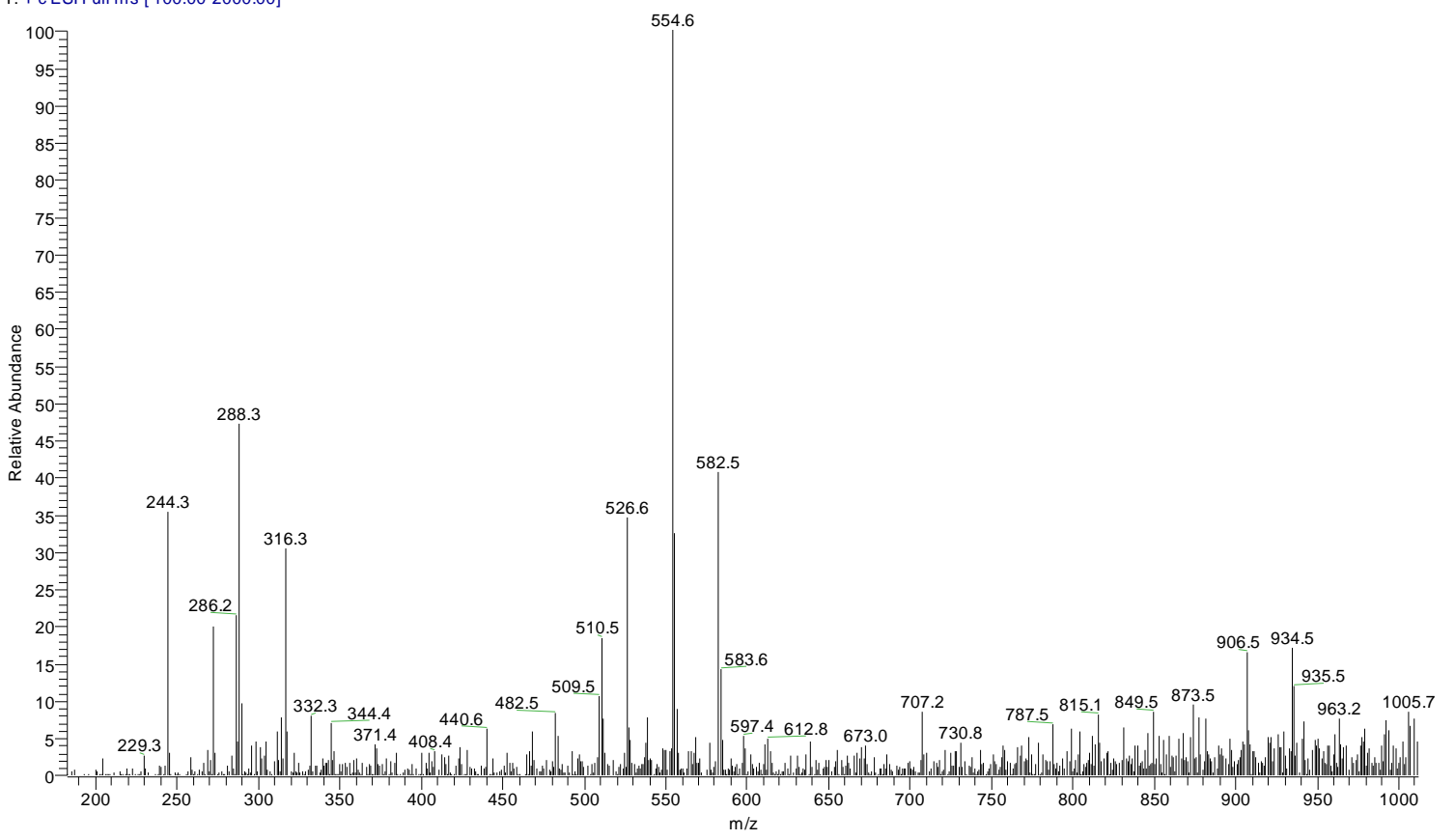


(B) Cleavage of $1^{\text {st }}$ bead selected for in RBDCC experiment. $(\mathrm{M}+1)=749.3 ;(\mathrm{M}+\mathrm{Na})=771.3$ ROC-MILLER-RBDCC-8B \#134-143 RT: 1.88-1.99 AV: 10 SB: 13 0.83-0.97 NL: 8.82E6

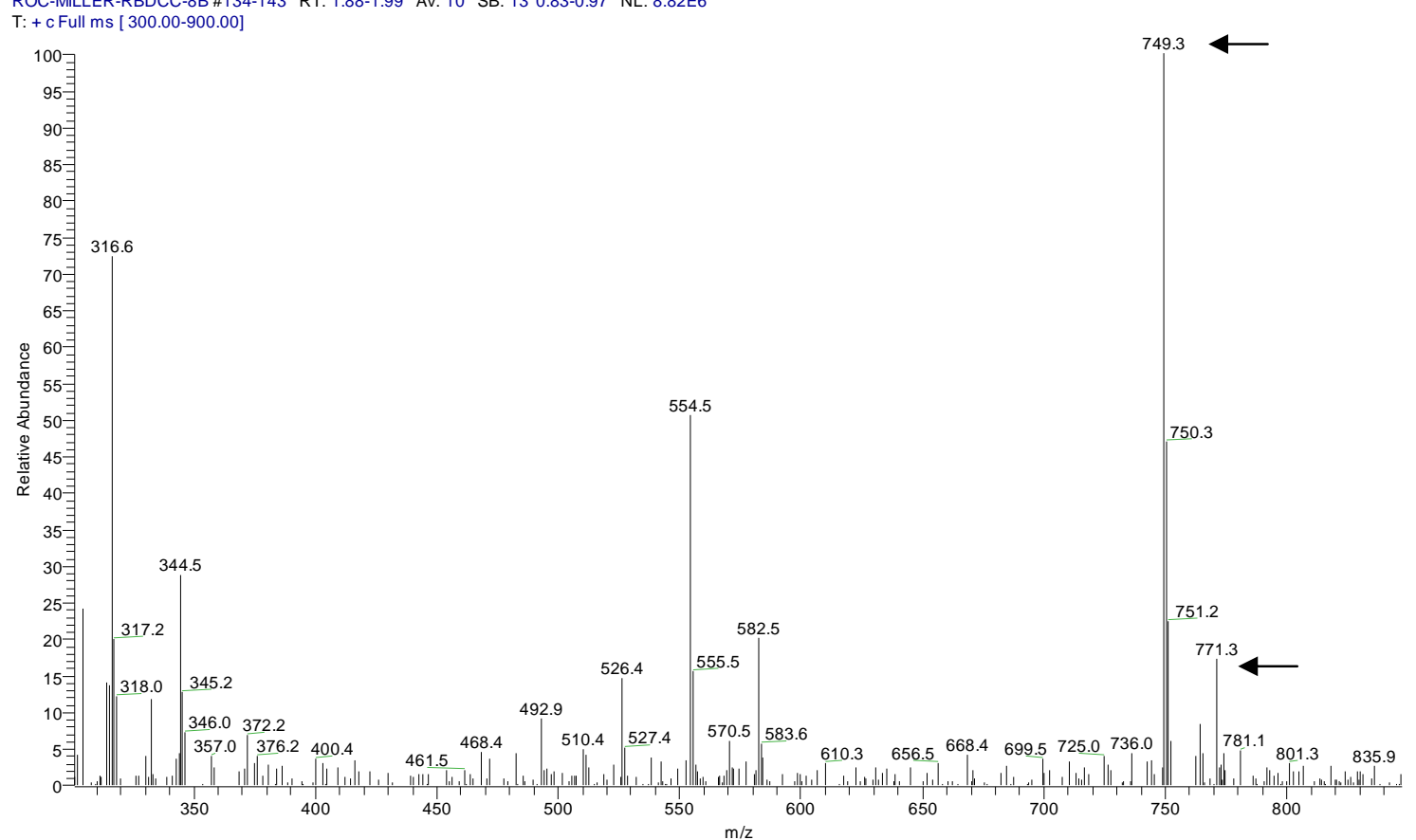

(C) Cleavage of $2^{\text {nd }}$ bead selected for in RBDCC experiment. $(\mathrm{M}+1)=640.2 ;(\mathrm{M}+\mathrm{Na})=662.3$ ROC-MILLER-RBDCC-9B \#139-149 RT: 1.96-2.07 AV: 11 SB: 15 0.78-0.95 NL: 1.11E7

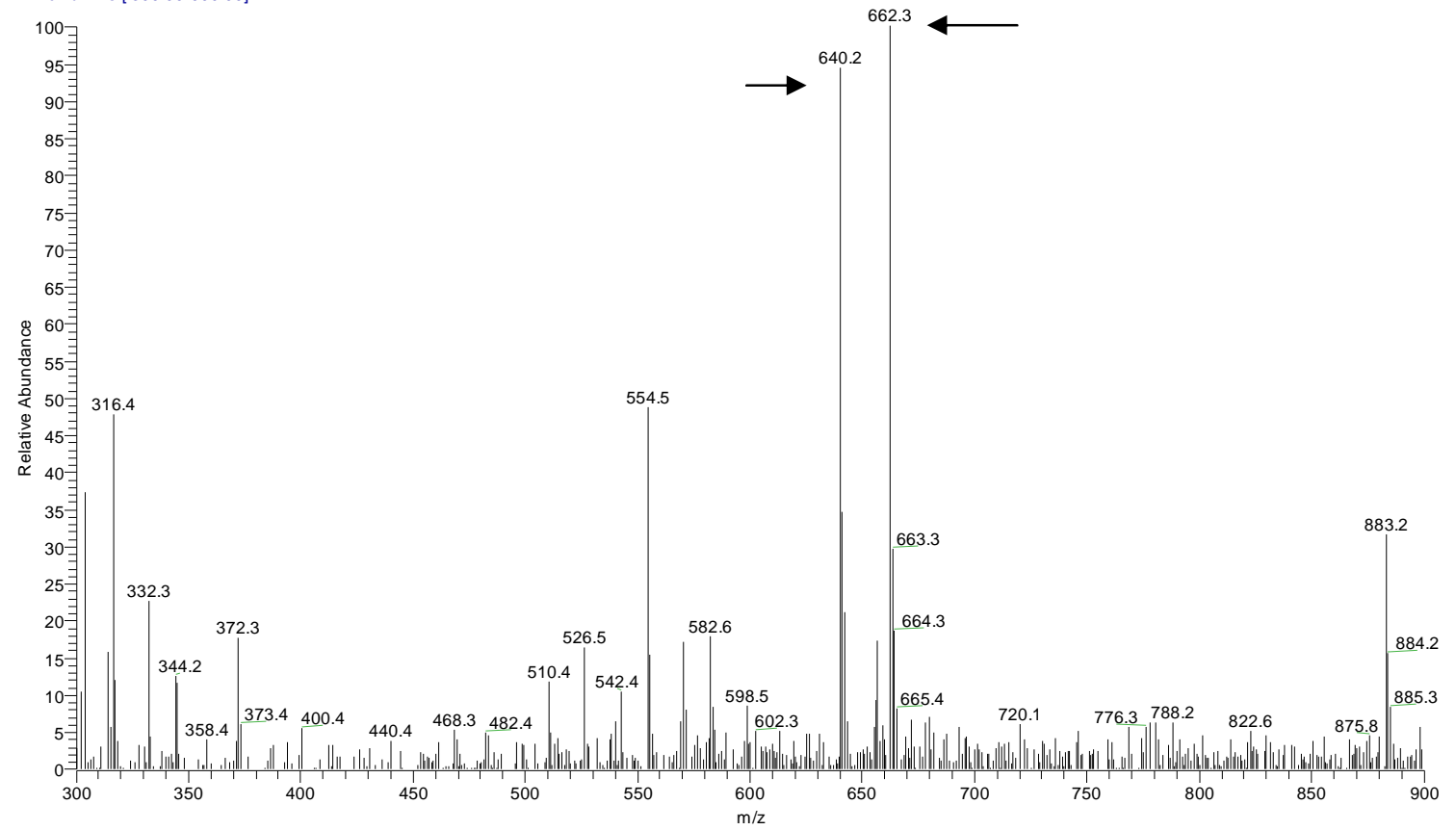


(D) Cleavage of $3^{\text {rd }}$ bead selected for in RBDCC experiment. $(\mathrm{M}+1)=741.3 ;(\mathrm{M}+\mathrm{Na})=763.1 ;(\mathrm{M}+2 / 2)=$ 371.4

ROC-MILLER-RBDCC-10B\#131-141 RT: 1.89-2.01 AV: 11 SB: 14 0.84-0.99 NL: 3.19E7

$\mathrm{T}:+\mathrm{c}$ Full ms [ $300.00-900.00]$

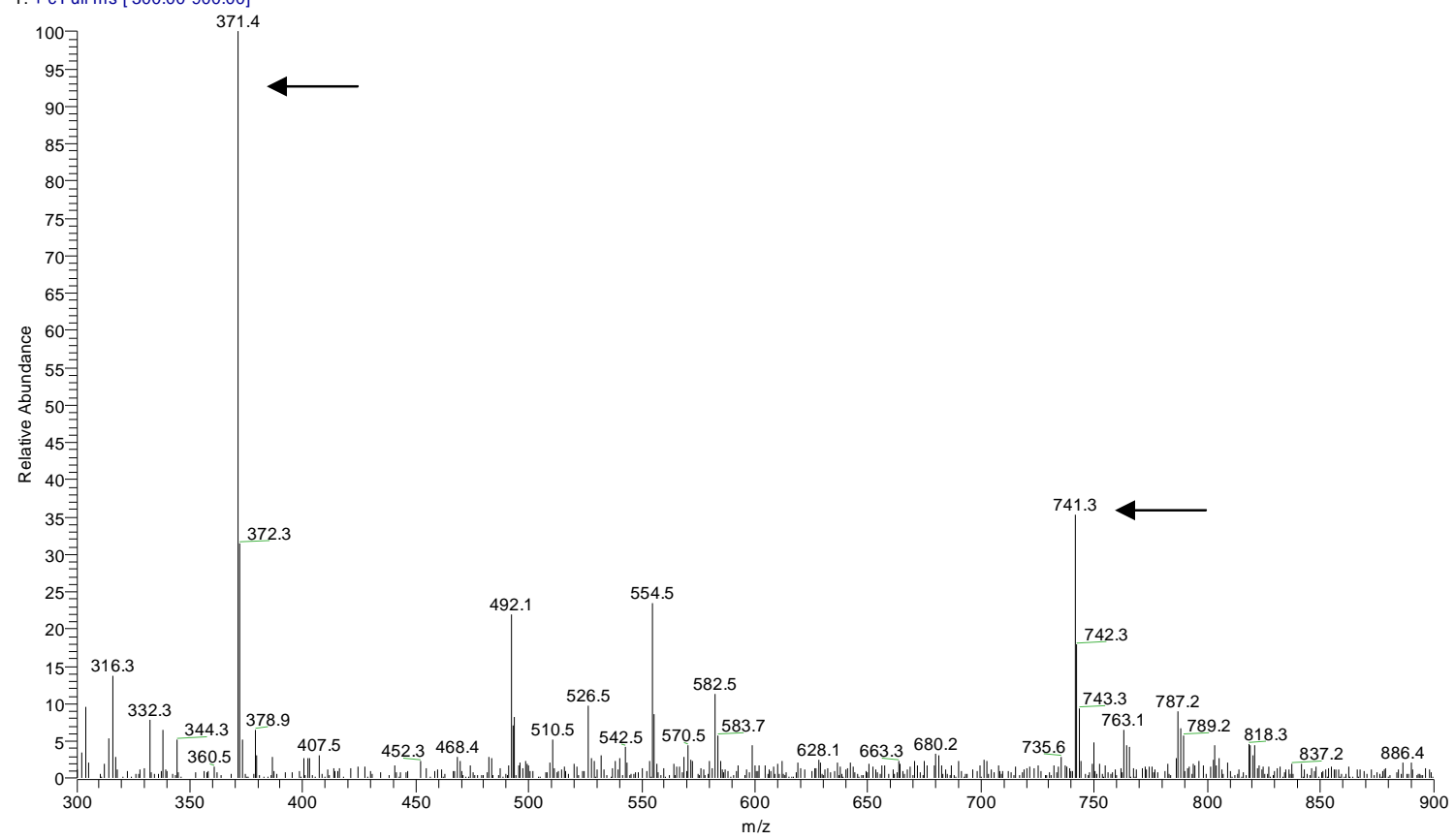

Figure S7 Chemical structure of building blocks selected for by RBDCC and identified by mass spectrometry as participating in the synthesis of high-affinity ligands.
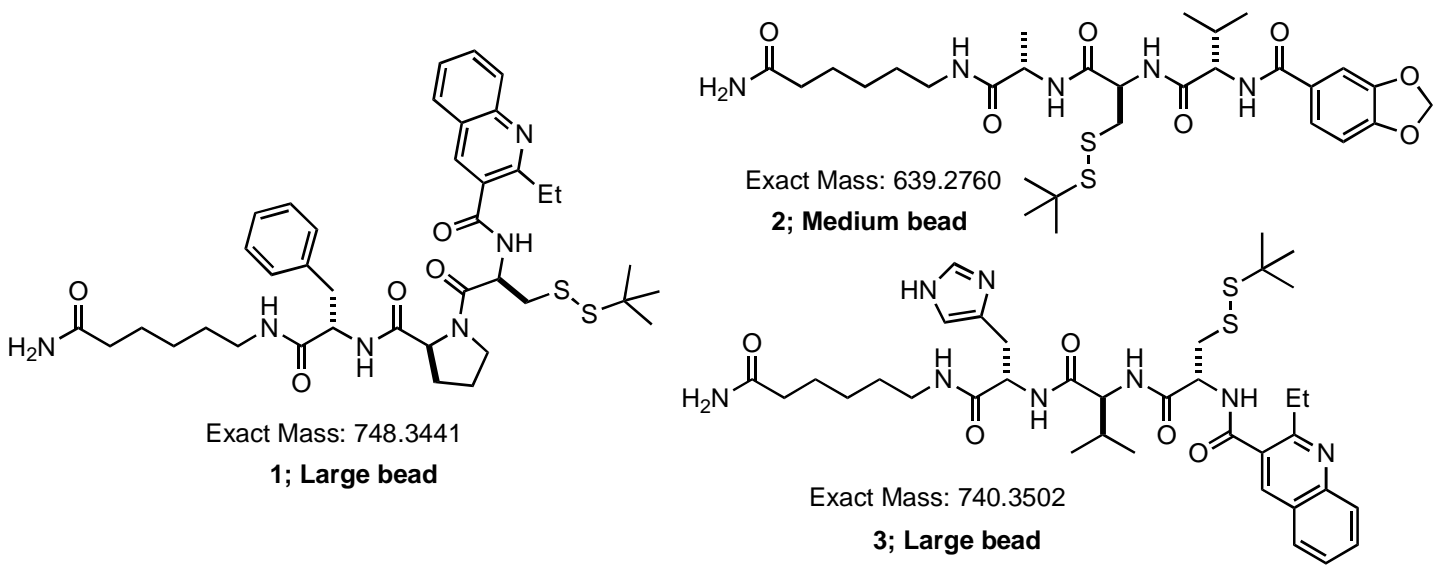

From these building blocks, the highest affinity ligand(s) were next determined. 1, 2, and 3 were individually synthesized on TentaGel $(0.86 \mathrm{nmol} / \mathrm{bead})$, and equilibrated as described above in separate vessels containing only $\mathbf{1}, \mathbf{2}$, or $\mathbf{3}$ and $500 \mathrm{nM}$ RNA, half the concentration used in the initial screen. After 72 hours the resin was washed identical to the conditions of screen number 4 and analyzed by fluorescence microscopy (50 $\mathrm{msec}$. exposure). As shown in Figure S8, dimers 1-1 and 1-3 were found to have the highest affinity for the RNA stem-loop. 
Interestingly, while compound 1-3 exhibits high levels of fluorescence intensity, 3-1 did not. This highlights an important feature of RBDCC, the ability to readily identify highest affinity compounds due to competition between solid phase and solution phase components. As shown in Figure 4, dimer 1-1 exhibits high affinity for the RNA stem-loop. Therefore, when resin bearing 3 is equilibrated with solution phase $\mathbf{1}$ and RNA, a competition between solution phase homo-dimer 1-1 and resin bound hetero-dimer 3-1 ensues. After equilibration, RNA bound by solution phase 1-1 is washed away from the resin. Conversely, dimer 3-3 was shown to have relatively low affinity for the stem-loop. Therefore, resin bound hetero-dimer 1-3 easily out competes solution phase 3-3 and the RNA remains bound to the resin, thus exhibiting a high fluorescence intensity.

Figure S8. Identification of highest-affinity ligands by a refined resin-bound dynamic combinatorial library. Numbering scheme $x-y ; x=$ monomer attached to bead, $y=$ solution phase species.
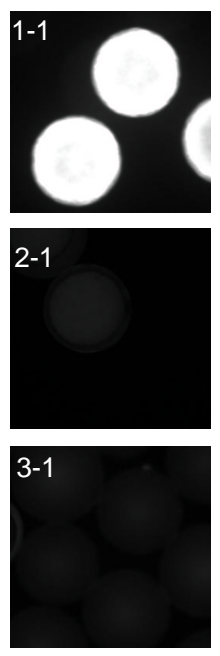
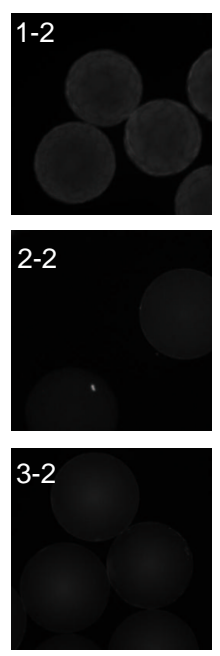
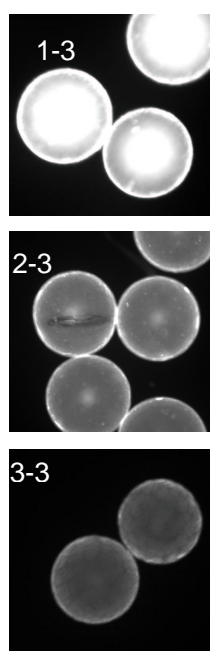

\section{Preparation and spectral analysis of 1-1/1-3.}

Dimers 1-1 and 1-3 were prepared as follows: Monomers 1 and $\mathbf{3}$ were prepared as previously on 3 grams Wang resin using Cys(Trt)-OH. After synthesis was complete, the trityl group was removed through the addition of 2\% TFA / DCM for 30 minutes. This was repeated twice to assure removal of this group. Mass spectrometry analysis of the resulting solution showed the presence of the trityl species and not cleaved monomer. After washing the resin, it was split into two $500 \mathrm{mg}$ aliquots. A $2 \mathrm{~g}$ aliquot of resin $(2.0 \mathrm{mmol})$ was cleaved by addition of $50 \%$ TFA/ $1 \%$ TES / DCM for 1 hour, and ether precipitated as described previously. To 100 $\mathrm{mg}$ of Wang monomeric resin $(0.1 \mathrm{mmol}, 1$ eq. $)$ was added $5 \mathrm{ml}$ of a $0.2 \mathrm{M}, 0.1 \%$ DMSOphosphate buffer solution (1.0 mmol, 10 eq.) of either monomer 1 or $\mathbf{3}$. This solution was agitated for 24 hours, drained, and a fresh solution of monomer was added and agitated for an additional 24 hours. After such time the resin was washed, cleaved, and ether precipitated as described previously. The precipitate, an off white powder was dried by lyophilzation and analyzed. 
Note: Due to cleavage conditions from the solid support, compounds exhibit peaks in the ${ }^{13} \mathrm{C}$ spectra from TFA $(163 \mathrm{ppm}(\mathrm{q}, \mathrm{J}=155 \mathrm{~Hz}), 116 \mathrm{ppm}(\mathrm{q}, \mathrm{J}=1125 \mathrm{~Hz})$. These peaks are not listed in the spectral analysis below.

\section{Spectra (IR, $\left.{ }^{1} \mathrm{H},{ }^{13} \mathrm{C}, \mathrm{HRMS}\right)$.}

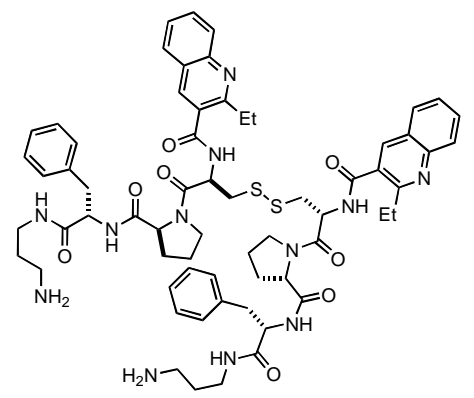

\section{1-1}

${ }^{1} \mathrm{H}\left(400 \mathrm{MHz}, \mathrm{CD}_{3} \mathrm{OD}\right): 8: 9.02(1 \mathrm{H}, \mathrm{s}) ; 8.18-8.17(1 \mathrm{H}, \mathrm{m}) ; 8.11-8.08(2 \mathrm{H}, \mathrm{m}) ; 7.88-7.86(1 \mathrm{H}, \mathrm{m}) ; 7.28(2 \mathrm{H}, \mathrm{t}, \mathrm{J}=8$ $\mathrm{Hz}) ; 7.24(1 \mathrm{H}, \mathrm{t}, \mathrm{J}=6 \mathrm{~Hz}) ; 7.16(2 \mathrm{H}, \mathrm{d}, \mathrm{J}=8 \mathrm{~Hz}) ; 4.98(1 \mathrm{H}, \mathrm{t}, \mathrm{J}=6 \mathrm{~Hz}) ; 4.47-4.41(1 \mathrm{H}, \mathrm{m}) ; 3.94(2 \mathrm{H}, \mathrm{d}, \mathrm{J}=6 \mathrm{~Hz})$; 3.89-3.83 (1H, m); 3.75-3.64 (1H, m); $3.23(2 \mathrm{H}, \mathrm{q}, \mathrm{J}=8 \mathrm{~Hz}) ; 2.96(2 \mathrm{H}, \mathrm{d}, \mathrm{J}=8 \mathrm{~Hz}) ; 2.67(2 \mathrm{H}, \mathrm{t}, \mathrm{J}=6 \mathrm{~Hz}) ; 2.23-$ $2.18(1 \mathrm{H}, \mathrm{m}) ; 2.05-1.93(1 \mathrm{H}, \mathrm{m}) ; 1.86-1.79(1 \mathrm{H}, \mathrm{m}) ; 1.76-1.70(1 \mathrm{H}, \mathrm{m}) ; 1.65(2 \mathrm{H}, \mathrm{t}, \mathrm{J}=7 \mathrm{~Hz}) ; 1.35(3 \mathrm{H}, \mathrm{t}, \mathrm{J}=8$ $\mathrm{Hz})$.

${ }^{13} \mathrm{C}\left(75 \mathrm{MHz}, \mathrm{CD}_{3} \mathrm{OD}\right): \delta: 173.6,172.9,172.8,170.0,166.7,160.4,145.2,138.1,136.1,130.1,129.4,129.0,128.9$, $128.7,128.5,127.1,126.4,119.7,60.6,60.5,55.2,54.3,48.1,36.7,35.9,29.2,26.3,26.1,24.4,13.5$.

IR (neat): $\mathrm{cm}^{-1}: 1761,1666,1640,1530,1522,1440,1286,1199,1173,1159,883,788,756,720,701$, HRMS $m / z$ calculated for $\left(\mathrm{M}^{+}+\mathrm{H}\right)$; 1207.5585 , found: 1207.5593 .

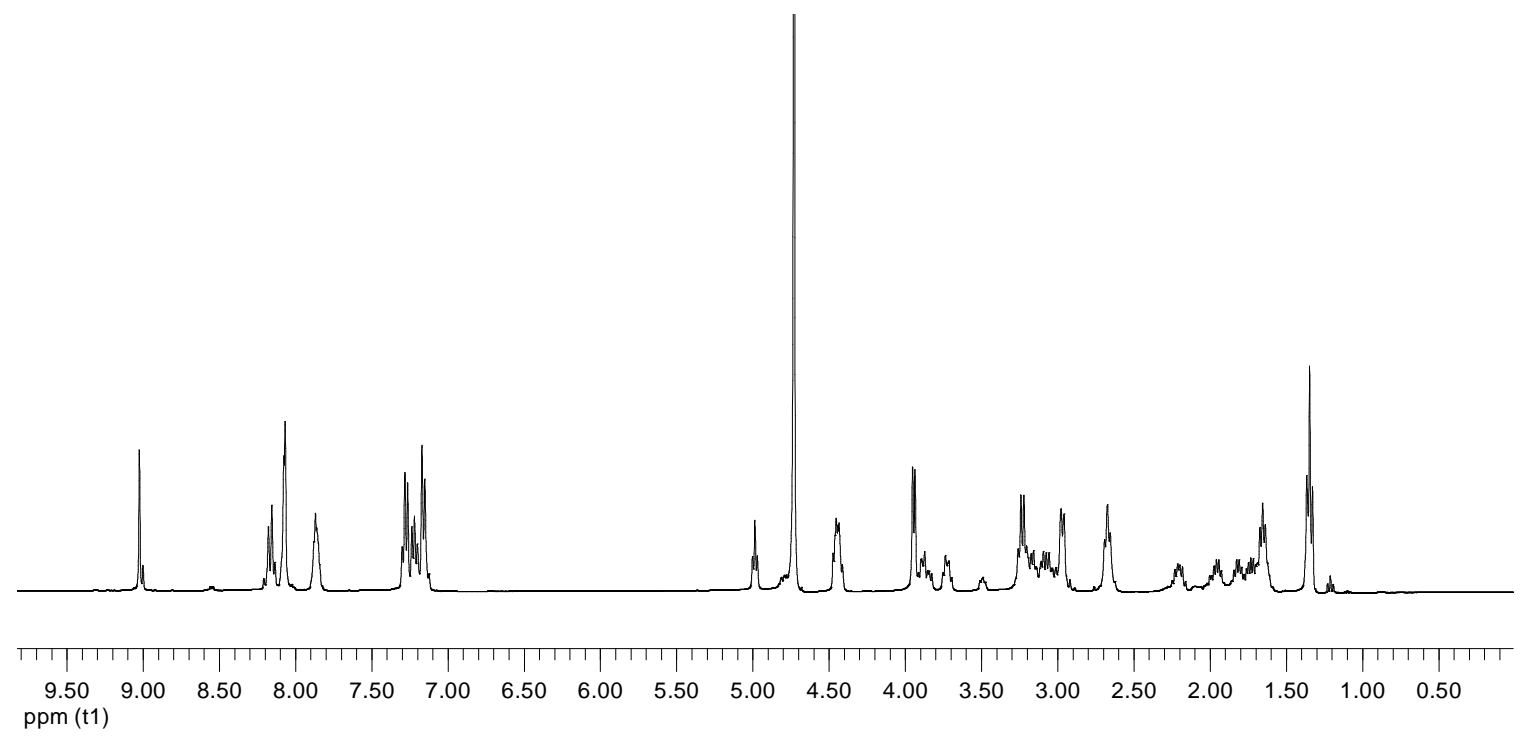


McNaughton, B.R.; Gareiss, P.C.; Miller, B.L. Supporting Data (S12)
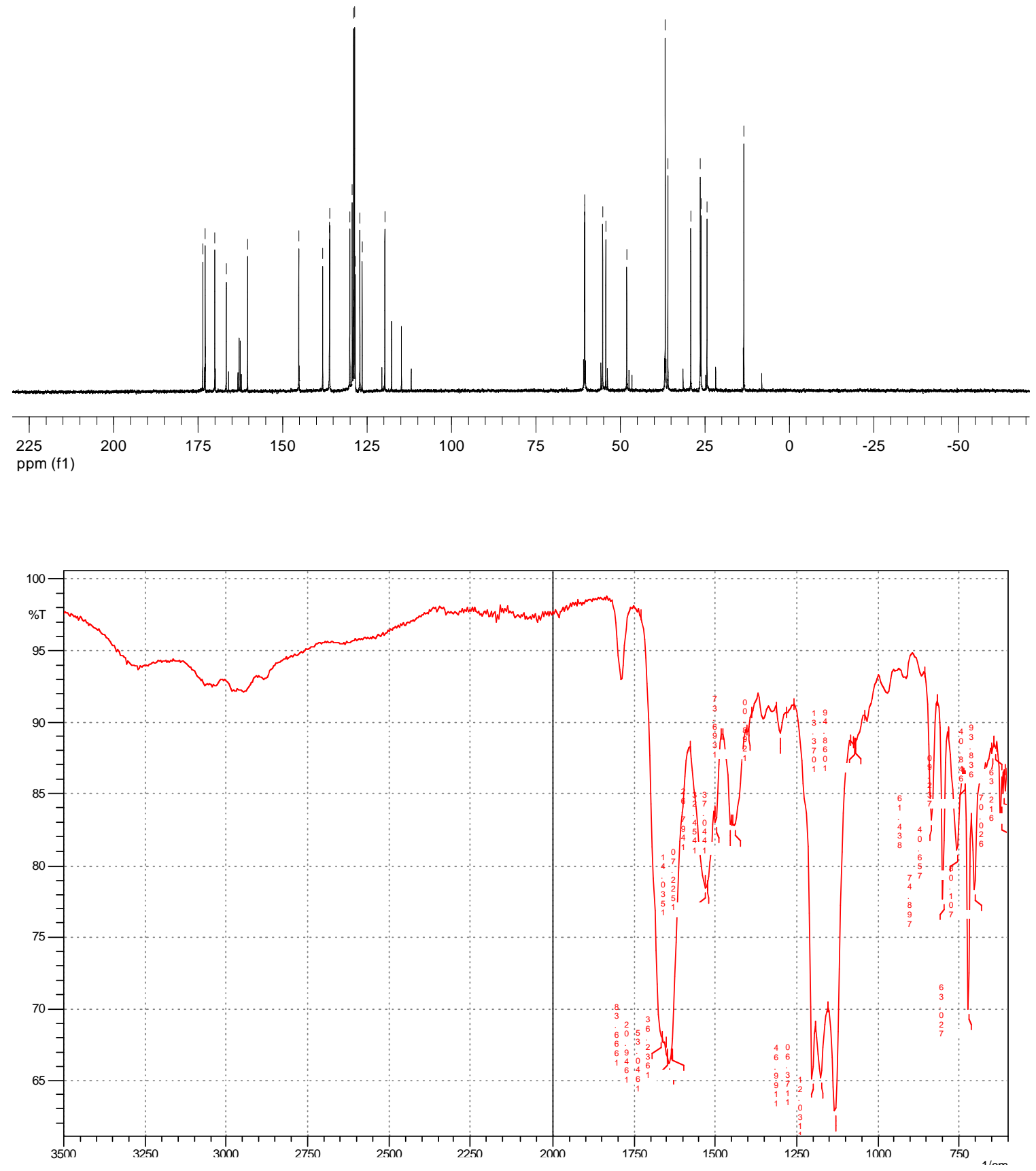


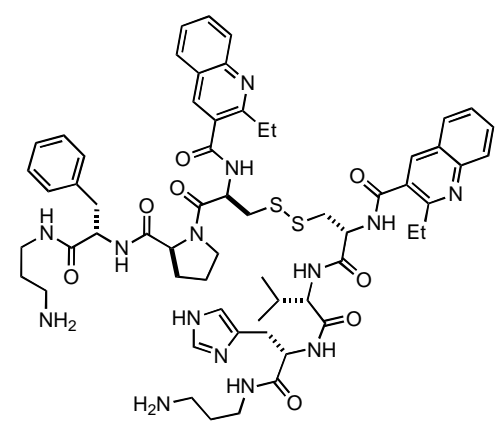

\section{1-3}

IR (neat): $\mathrm{cm}^{-1} ; 1760,1640,1519,1454,1201,1175,1130,834,798,754,720,701$

${ }^{1} \mathrm{H}$ NMR $\left(400 \mathrm{MHz}, \mathrm{D}_{2} \mathrm{O}\right) \delta: 8.69(1 \mathrm{H}, \mathrm{s}) ; 8.67(1 \mathrm{H}, \mathrm{s}) ; 8.62(1 \mathrm{H}, \mathrm{d}, \mathrm{J}=1.2 \mathrm{~Hz}) ; 8.00(1 \mathrm{H}, \mathrm{s}) ; 7.98(1 \mathrm{H}, \mathrm{s}) ; 7.93$ $(3 \mathrm{H}, \mathrm{t}, \mathrm{J}=2.8 \mathrm{~Hz}) 7.72(2 \mathrm{H}, \mathrm{m}) ; 7.75-7.68(2 \mathrm{H}, \mathrm{m}) ; 7.34-7.30(3 \mathrm{H}, \mathrm{m}) ; 7.22-7.18(3 \mathrm{H}, \mathrm{m}) ; 7.28-7.26(1 \mathrm{H}, \mathrm{m}) ; 5.01$ $(1 \mathrm{H}, \mathrm{t}, \mathrm{J}=6.4 \mathrm{~Hz}) ; 4.69-4.65(1 \mathrm{H}, \mathrm{m}) ; 4.51-4.47(2 \mathrm{H}, \mathrm{m}) ; 4.18(1 \mathrm{H}, \mathrm{d}, \mathrm{J}=7.4 \mathrm{~Hz}) ; 3.98(2 \mathrm{H}, \mathrm{d}, \mathrm{J}=7.2 \mathrm{~Hz})$; $3.92-$ $3.88(1 \mathrm{H}, \mathrm{m}) ; 3.78-3.72(1 \mathrm{H}, \mathrm{m}) ; 3.33-3.25(2 \mathrm{H}, \mathrm{m}) ; 3.25-3.19(2 \mathrm{H}, \mathrm{m}) ; 3.19-3.09(7 \mathrm{H}, \mathrm{m}) ; 3.07-2.93(5 \mathrm{H}, \mathrm{m}) ; 2.74$ $(2 \mathrm{H}, \mathrm{t}, \mathrm{J}=6.8 \mathrm{~Hz}) ; 2.27-2.17(1 \mathrm{H}, \mathrm{m}) ; 2.12-2.05(1 \mathrm{H}, \mathrm{m}) ; 2.01-1.94(1 \mathrm{H}, \mathrm{m}) ; 1.90-1.81(3 \mathrm{H}, \mathrm{m}) ; 1.79-1.68(3 \mathrm{H}, \mathrm{m})$; $1.34-1.28(4 \mathrm{H}, \mathrm{m}) ; 1.26(3 \mathrm{H}, \mathrm{t}, \mathrm{J}=7.2) ; 0.97-0.91(4 \mathrm{H}, \mathrm{m})$.

${ }^{13} \mathrm{C}$ NMR $\left(75 \mathrm{MHz}, \mathrm{D}_{2} \mathrm{O}\right) \delta: 173.6,173.0,172.9,171.5,171.4,171.3,170.2,167.9,160.5,160.4,142.0,141.8$, 141.2, 141.1, 136.1,134.4, 134.3, 133.5, 129.0, 128.9, 128.7, 128.4, 128.3, 127.1, 125.9, 122.2, 122.1, 117.7, 60.6, 59.6, 56.2, 55.2, 54.1, 53.8, 52.6, 48.1, 46.6, 36.9, 36.7, 36.5, 36.2, 35.9, 30.1, 29.1, 27.2, 26.5, 26.4, 26.2, 25.0, $24.3,18.2,17.6,13.6,8.1$.

HRMS $m / z$ calcd for $\left(\mathrm{M}^{+}+\mathrm{H}\right) ; 1199.5641$, found: 1199.5634 .
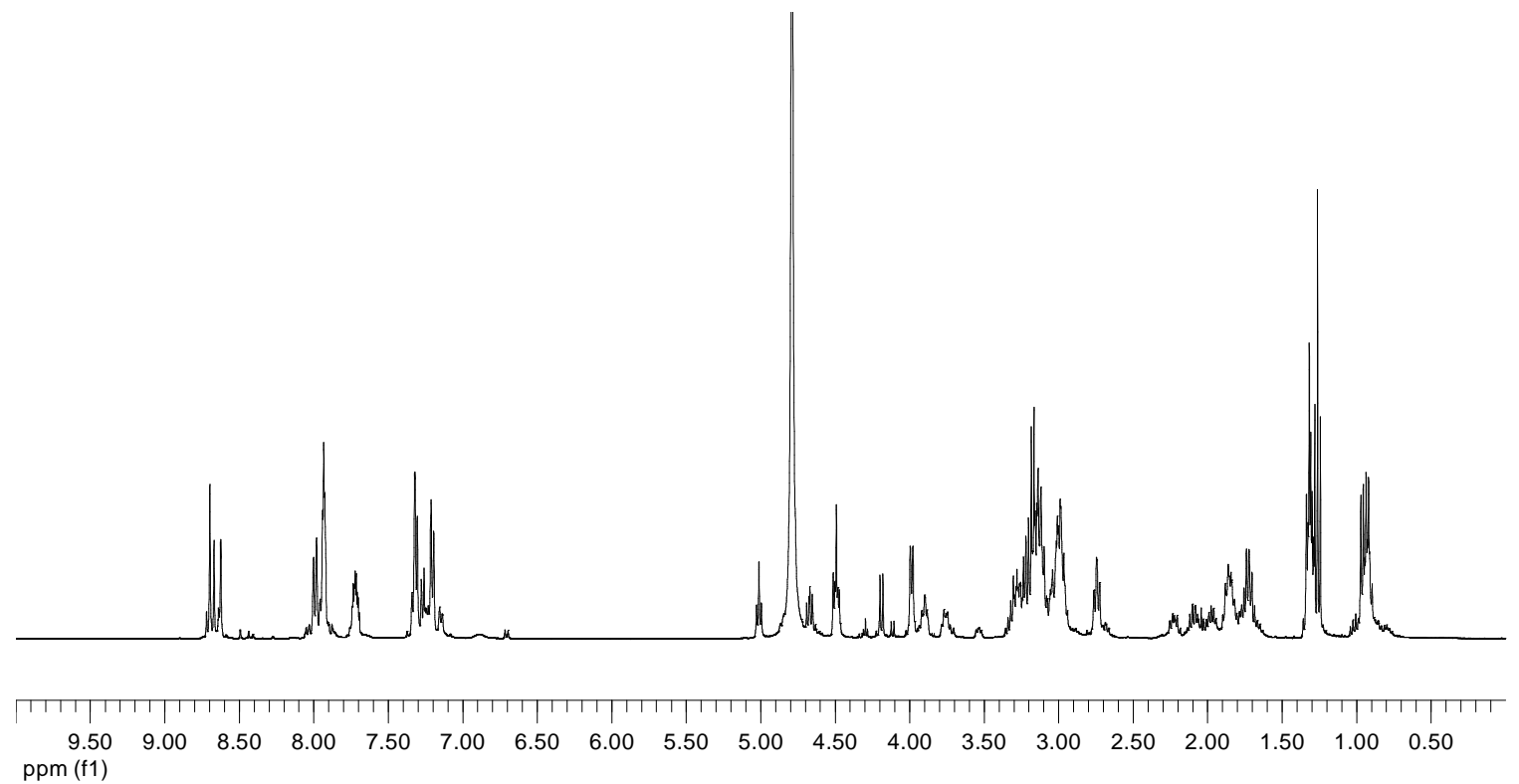
McNaughton, B.R.; Gareiss, P.C.; Miller, B.L. Supporting Data (S14)
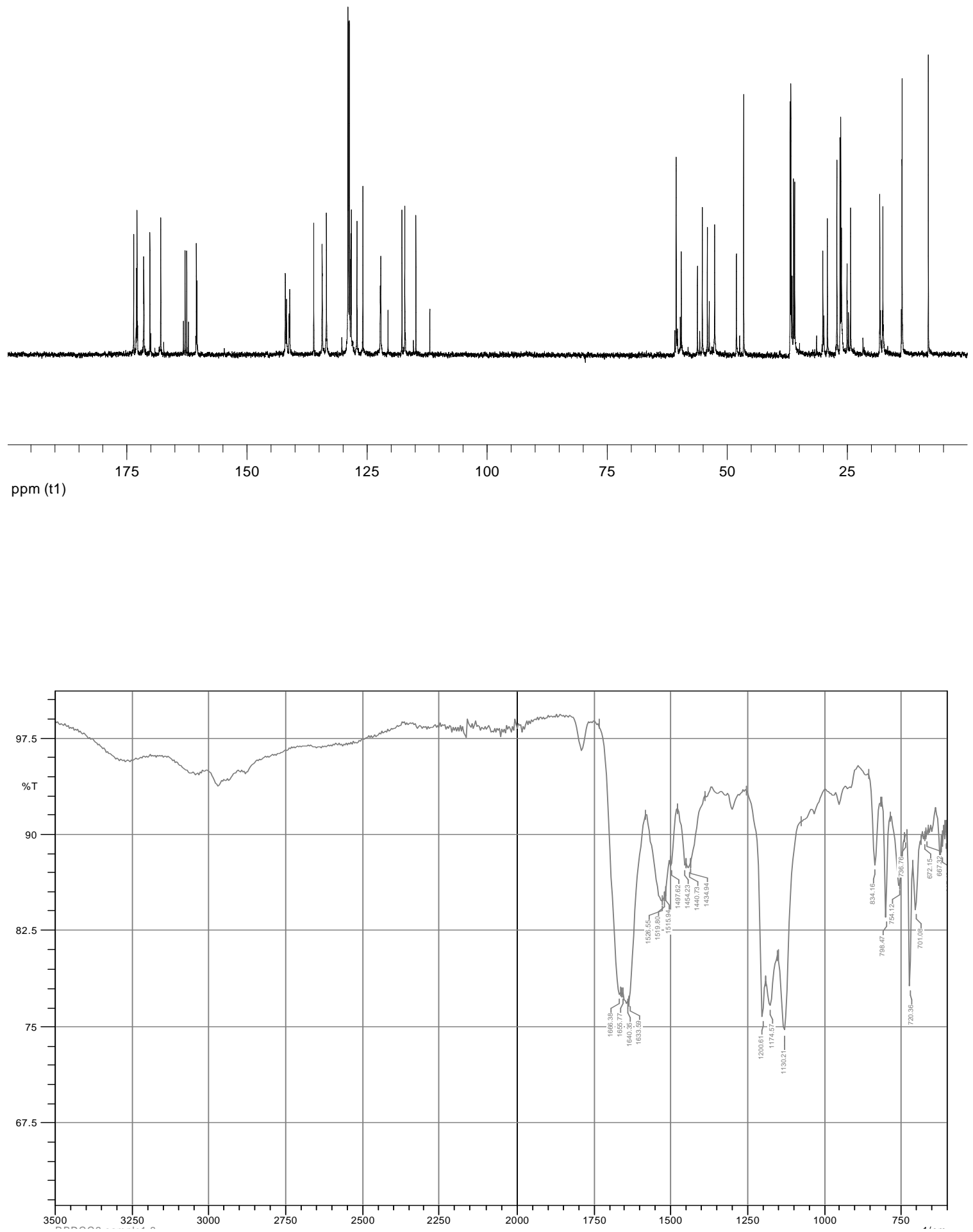
McNaughton, B.R.; Gareiss, P.C.; Miller, B.L. Supporting Data (S15)

\section{Surface Plasmon Resonance (SPR) Analysis.}

SPR analysis was conducted on a Reichert SR7000 Refractometer equipped with a 100 $\mu \mathrm{L}$ injection loop. For all experiments the flow rate was $10 \mu \mathrm{L} / \mathrm{min}$, the running buffer was $\mathrm{PBST}^{5}$, and the injection size was $130 \mu \mathrm{L}$. The various RNA and DNA ligand solutions were $15.3 \mathrm{nM}, 62.5 \mathrm{nM}, 250 \mathrm{nM}, 500 \mathrm{nM}, 1 \mu \mathrm{M}, 2 \mu \mathrm{M}, 10 \mu \mathrm{M}$, and $50 \mu \mathrm{M}$ in PBST. Stocks of 1 $\mathrm{mg} / \mathrm{mL}$ of compounds 1-1 and 1-3 were made in $20 \mathrm{mM}$ sodium acetate buffer, $\mathrm{pH} 5.5$ for immobilization to the sensor slides. Reichert gold sensor slides consisting of a mixed selfassembled monolayer of thiol-PEG-alcohols and thio-PEG-carboxylic acids ( 9:1; PEG = polyethylene glycol) were used. The sensor slide was activated using standard EDC/NHS coupling to the carboxy termini of the surface for 10 minutes, followed by a 3 minute PBST wash. Compounds 1-1 and 1-3 were covalently attached to the activated surface for 10 minutes, resulting in $\mathrm{a} \sim 450 \mu \mathrm{RIU}$ increase. Unreacted activated esters were deactivated with $1 \mathrm{M}$ ethanolamine at $\mathrm{pH} 8.5$ for 10 minutes, and the chip surface was regenerated with $10 \mathrm{mM}$ glycine at $\mathrm{pH} 2.0$ for 3 minutes. A 5 minute injection of PBST reestablished the signal baseline. Each concentration of ligand was injected over 7 minutes (association), followed by 5 minutes of PBST flow (dissociation), followed by a 3 minute injection of $10 \mathrm{mM}$ glycine at $\mathrm{pH} 2.0$ and 3 minutes of PBST flow (regeneration), and a 3 minute injection of PBST (baseline reestablishment). Data were analyzed using the SPR_V4013 software (QuanTraq), and curves for each RNA or DNA concentration were exported for analysis in Scrubber 2.0 (provided by David Myszka at the University of Utah and Biologic Software Ltd Pty, Australia). Similar control experiments were performed by injecting the various concentrations of RNA and DNA over a "blank" sensor slide that was treated with EDC/NHS followed by blocking with ethanolamine to ensure the observed $\Delta \mu \mathrm{RIU}$ was not due to non-specific absorption of the sequences to the sensor slide. All traces were zeroed, cropped, aligned, and analyzed for concentration dependent changes in the steady-state signal. Dissociation constants were determined by plotting the total steady state $\Delta \mu \mathrm{RIU}$ values using DeltaGraph and fitting using a logistic fit (Equation S1).

Equation S1: Logistic Curve Fit

$$
y=\frac{A-B}{1+\left(\frac{x}{x_{0}}\right)^{p}}+B
$$

$$
\text { Where; } A=\min ; \mathrm{B}=\max ; \mathrm{x}=[\mathrm{RNA}] ; \mathrm{x}_{\mathrm{o}}=\mathrm{K}_{\mathrm{d}} ; \mathrm{p}=\text { power }
$$

Binding affinity was tested using the HIV-1 slippery sequence inducing stem-loop (I), used in the selection experiments. Selectivity was evaluated using an analogous DNA sequence

\footnotetext{
${ }^{5}$ PBST tablets (BioChemika Ultra, pH 7.4, contains Tween 20, tablets (Fluka) purchased from Sigma Aldrich) were dissolved in sterile $\mathrm{H}_{2} \mathrm{O}$ to yield a final buffer composition of $0.01 \mathrm{M}$ phosphate buffer, $0.0027 \mathrm{M} \mathrm{KCl}, 0.14 \mathrm{M} \mathrm{NaCl}, 0.05 \%$ Tween 20, pH 7.4.
} 
(II), a differing RNA stem-loop (III), a stem-loop where the loop region was changed from ACAA to CACC (IV), and a shortened stem-loop (V) (Figure S9).

Binding affinity of compound 1-1 to RNA Sequence 1 was confirmed in duplicate by a similar SPR analysis on a dual channel Reichert SR7000DC instrument as described above. Similarly, the reference channel was blocked by treatment with EDC/NHS followed by ethanolamine. The total steady state $\Delta \mu \mathrm{RIU}$ of the reference channel were subtracted from those of the sample channel after each injection, and analyzed as above.

Figure S9 (I) HIV-1 frameshift regulatory stem-loop; (II) Analogous DNA stem-loop; (III) Alternate RNA stem-loop; (IV) Stem-loop featuring different loop region; (V) Shortened HIV-1 frameshift regulatory stem-loop.

\begin{tabular}{|c|c|c|c|c|}
\hline I & II & III & IV & $\mathbf{V}$ \\
\hline$C A$ & $C A$ & \multirow[b]{3}{*}{$C G$} & $A C$ & C A \\
\hline A A & A A & & $\mathrm{C} C$ & A $A$ \\
\hline C-G & $C-G$ & & C-G & C-G \\
\hline C-G & C-G & $U \quad U$ & C-G & C-G \\
\hline C-G & C-G & U-A & $C-G$ & C-G \\
\hline U-A & $T-A$ & $C-G$ & U-A & $U-A$ \\
\hline U-A & $\mathrm{T}-\mathrm{A}$ & $U-A$ & U-A & \\
\hline C-G & C-G & G-C & C-G & \\
\hline C-G & C-G & $\mathrm{A}-\mathrm{U}$ & C-G & \\
\hline $\mathrm{G}-\mathrm{C}$ & G-C & U-A & $G-C$ & \\
\hline G-C & G-C & & $G-C$ & \\
\hline
\end{tabular}

\begin{tabular}{|c|c|c|c|c|c|}
\hline $\operatorname{Kd}(\mathbf{1 - 1})$ & $\begin{array}{c}4.1 \pm 2.4 \\
\mu \mathrm{M}(4 \\
\text { replicate } \\
\text { titrations })\end{array}$ & $>90 \mu \mathrm{M}$ & $\begin{array}{c}\text { No measurable } \\
\text { affinity }\end{array}$ & $\begin{array}{c}\text { No measurable } \\
\text { affinity }\end{array}$ & $\begin{array}{c}\text { No measurable } \\
\text { affinity }\end{array}$ \\
\hline
\end{tabular}




\section{tRNA \\ 7. Binding of Cy3-tagged RNA sequence I to bead-bound 1-1 in the presence of}

To test the ability of dimer 1-1 to bind to RNA sequence I in the presence of excess tRNA, a solid phase approach was employed. Dimer 1-1 was prepared on beads as described earlier. Similarly, aliquots of beads bearing compound 1-1 or monomer 1 (10 beads 8.6 nmole) were placed in reaction vessels. Four experiments were set up in total volumes of $1 \mathrm{~mL} \mathrm{PBS} \mathrm{pH}$ 7.2, with incubation times of 3 hours. First beads bearing 1-1 were incubated in the presence of $500 \mathrm{nM}$ Cy-3 RNA sequence I. Second, beads bearing 1-1 were incubated in the presence of 500 nM Cy-3 RNA sequence I and $100 \mu \mathrm{M}$ tRNA. Third, to control for any nonspecific affinity of the Cy-3 RNA sequence I to the resin, resin bearing only monomer 1 was incubated in the presence of $500 \mathrm{nM} \mathrm{Cy-3} \mathrm{RNA} \mathrm{sequence} \mathrm{I.} \mathrm{Fourth,} \mathrm{to} \mathrm{control} \mathrm{for} \mathrm{any} \mathrm{intrinsic} \mathrm{fluorescence} \mathrm{of}$ tRNA and the resin, resin bearing 1-1 was incubated in the presence of $100 \mu \mathrm{M}$ tRNA. After the incubation, the beads were washed $3 \times 1 \mathrm{~mL}$ PBS and imaged as previously described with varying exposure times. The exposure times are listed under each picture in Figure S10.

It is clearly evident that beads bearing compound 1-1 are able to bind to the Cy-3 labeled RNA sequence I efficiently, both in the absence and presence of $100 \mu \mathrm{M}$ total yeast tRNA.

Figure S10: Fluorescence microscopy images of resin beads bearing 1 or 1-1, in the presence of Cy3-tagged RNA sequence I and / or tRNA. All exposures are identical.

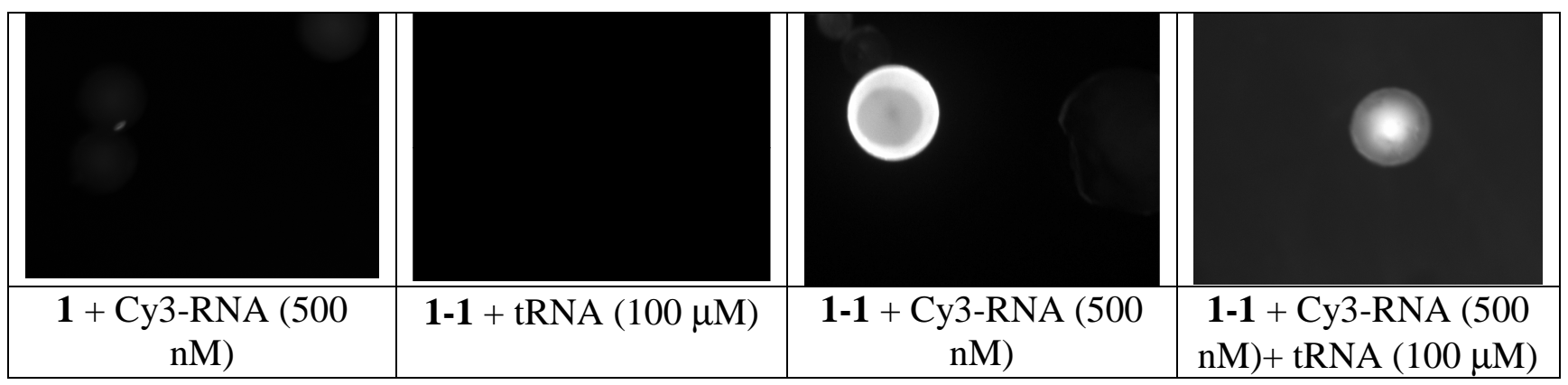

